Article

\title{
Human health risk assessment of nitrate and trace metals via groundwater in central Bangladesh
}

\author{
Md. Mostafizur Rahman ${ }^{1 *}$, Md. Bodrud-Doza², Md. Iftakharul Muhib ${ }^{3}$, Kaniz Fatima Binte \\ Hossain ${ }^{4}$, Md. Sabbir Hossain ${ }^{1}$, Sharmin Akter ${ }^{1}$, Md. Tajuddin Sikder ${ }^{5}$, Mashura Shammi ${ }^{1}$, \\ M Khabir Uddin ${ }^{1}$
}
${ }^{1}$ Department of Environmental Sciences, Jahangirnagar University, Dhaka, Bangladesh.rahmanmm@juniv.edu 2International Centre for Climate Change and Development, Bangladesh
${ }^{3}$ Department of Textile Engineering, City University, Bangladesh
${ }^{4}$ Graduate School of Environmental Science, Hokkaido University, Japan
${ }^{5}$ Department of Public Health and Informatics, Jahangirnagar University, Dhaka, Bangladesh
*Correspondence: rahmanmm@juniv.edu; Tel.: +8801717514833

\begin{abstract}
Groundwater plays a pivotal role as the largest potable water sources in Bangladesh. However, the quality of the groundwater faces challenges due to xenobiotic compounds in it. As agriculture is widely practiced in Bangladesh, potential nitrate $\left(\mathrm{NO}_{3}{ }^{-}\right)$pollution may appear in near future. Besides, excess amount of arsenic (As) has already been found in groundwater in many parts of Bangladesh including the present study area. Thus, this study was conducted to assess the water quality and associated human health risk in central Bangladesh. A total of 99 groundwater samples from the central part of Bangladesh were analyzed to assess human health risk due to high level of $\mathrm{NO}_{3}{ }^{-}$and other trace elements i.e. arsenic (As), iron (Fe), and manganese (Mn). Concentration of $\mathrm{NO}_{3}{ }^{-}$was determined using column chromatography and inductively coupled plasma optical emission spectrometer (ICPOES) was used to measure As, Fe and Mn concentrations. It was found that $\mathrm{NO}_{3}$ - concentration $(253.17 \mathrm{mg} / \mathrm{L})$ in the groundwater samples exceeds the recommended guideline value by the $\mathrm{WHO}(50 \mathrm{mg} / \mathrm{L})$. Moreover, this study area also characterized with elevated concentration of As $(19.44 \mu \mathrm{g} / \mathrm{L}), \mathrm{Fe}(811.35 \mu \mathrm{g} / \mathrm{L})$, and $\mathrm{Mn}(455.18 \mu \mathrm{g} / \mathrm{L})$ in the groundwater. Noncarcinogenic human health risk was calculated by justifying HQ (Hazard Quotient) and HI (Hazard Index) and attributed potential conjunctive human health risks due to $\mathrm{NO}_{3-}, \mathrm{As}, \mathrm{Fe}$ and $\mathrm{Mn}$ in the study area. Child (9.941) is more vulnerable than adult (7.810) considering non-carcinogenic human health risk. Moreover, high carcinogenic risk was found due to As contamination in the groundwater samples and children $\left(1.94 \times 10^{-3}\right)$ are more susceptible to carcinogenic risk compared to adults $\left(9.2 \times 10^{-4}\right)$.
\end{abstract}

Keywords: nitrate; arsenic; health risk assessment; hazard quotient; hazard index.

\section{Introduction}

Groundwater is one of the major drinking water sources in Bangladesh; however its quality has been degraded by human activities over the time. The presence of trace elements such as arsenic (As), iron $(\mathrm{Fe})$, manganese $(\mathrm{Mn})$ and nitrate $\left(\mathrm{NO}_{3}{ }^{-}\right)$in ground water is predominantly influenced by natural and anthropogenic sources [1, 2]. A line of evidence already suggested the possible sources of As in the groundwater of Bangladesh. For instance, geogenic processes, discharge of wastewater, smelters and mines, agricultural runoff, leakage from heavily contaminated areas and geothermal waters into ground water reservoir, could be the possible sources of metals in groundwater [2-5]. We have demonstrated the status of As contamination in Singair Upazila, Manikganj District and geogenic factors were found to be the major source of As in the groundwater in that area [2]. The quality of 
groundwater, such as concentration of trace elements is predominantly related to human health. Consumption of water contaminated with significant amount of trace elements via oral ingestion may cause serious health effects varying from shortness of breath to several types of cancers in human [6]. The consumption of As contaminated ground water is the main concern of As toxicity, skin lesion, gangrene in leg, cancer in lung, bladder, liver and skin etc., these diseases could be found among humans due to excessive consumption of As contaminated drinking water via oral ingestion pathway [7]. Fe and Mn also could accumulate into human body through drinking pathway [8]. Exposure to Mn could cause neurotoxicity [9] while gastrointestinal distress and dysfunction of multiple organs could occur due to iron consumption via drinking water [10-11]. Long term consumption of excessive $\mathrm{NO}_{3}{ }^{-}$can create cancer risk on human body due to formation of nitrosomines [12]. It has also been known to create spontaneous absorptions, birth defects, respiratory tract infections and changes in immune system [13-18]. Thus health risk assessment of these contaminants for predicting the health hazard is very important. According to United States Environment Protection Agency (USEPA), human health risk assessment is the process of estimating the nature and probability of adverse health effects in humans who may be susceptible to chemicals in contaminated environmental media, now or in the near future [19]. Mostly four steps must be followed to fulfill the health risk assessment e.g. identification of hazard, dose-response relationship, exposure assessment as well as risk characterization [20]. Thus, human health risk assessment is an effective way to justify health risk levels posed by various contaminants [21]. Oral ingestion is considered to be the route of exposure to chemical contaminants like $\mathrm{NO}_{3}^{-}, \mathrm{As}, \mathrm{Fe}, \mathrm{Mn}$ in ground water.

Considering the above facts, we hypothesized that the level of contaminants $\left(\mathrm{NO}_{3}{ }^{-}\right.$and trace metals) might be higher than acceptable level in central Bangladesh and could be major risk factor for human health. Therefore, the aim of this study was to determine the level of $\mathrm{NO}_{3}{ }^{-}$along with $\mathrm{As}$, Fe and $\mathrm{Mn}$ in groundwater and to evaluate the health risk associated with exposure to these contaminants via oral ingestion. This research may be the first attempt for assessing the health risk associated with $\mathrm{NO}_{3}{ }^{-}$and trace metals in the groundwater of central Bangladesh.

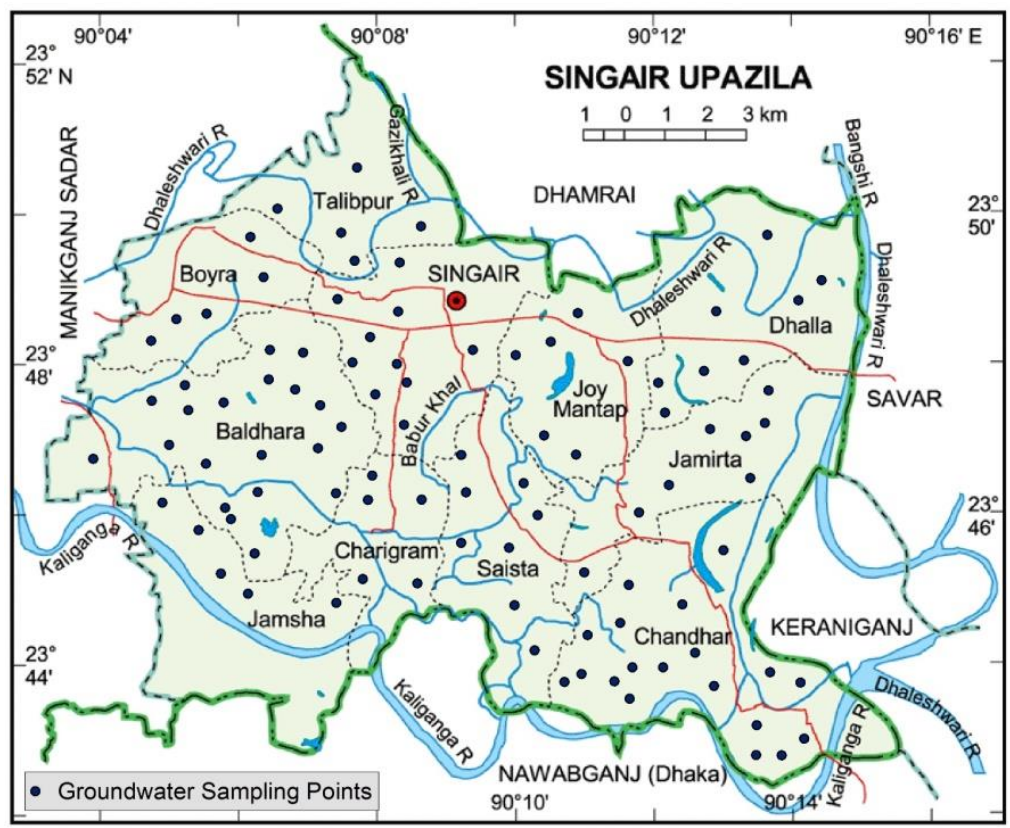

Figure 1. Map of the study area. 


\section{Materials and Methods}

Total 99 groundwater samples were collected from different depth depending on the tube-well bore depth $(\mathrm{m})$ in the central Bangladesh (Figure 1). The study area is located in Manikganj district Bangladesh. Sampling time is August 2011 and analysis was performed within 1 month from the sampling time. Before taking the sample the tube-well was pumped for around 10 minutes. All of the collected samples were stored in $250 \mathrm{ml}$ polypropylene plastic bottles with (for trace metal)/without $\left(\mathrm{NO}_{3}-\right)$ acidification by 2 drops of concentrated $\mathrm{HNO}_{3}$ to prevent any precipitations. The inductively coupled plasma (ICP-OES) optical emission spectrometer was used (SII NanoTechnology inc.) for the determination of $\mathrm{As}, \mathrm{Fe}$, and $\mathrm{Mn}$ as depicted else where [2]. Nitrate $\left(\mathrm{NO}_{3}{ }^{-}\right)$was determined by chromatography method (DX-120, Dionex, USA) using the columns "Ion Pac AS12A" (Dionex, Abbreviation of state, USA). Samples were filtered with glass fiber filters with $0.45 \mu \mathrm{M}$ pore. All the samples were analyzed triplicate for ensuring reproducibility and statistical validity. Statistical analysis was done by MS-excel 2007 and Principal Component Analysis (PCA) was done by using Origin 9.0 software (OriginLab, USA).

\subsection{Risk Analysis}

Risk assessment is the process of estimating the occurrence probability of any given magnitude of adverse health effects over a specified time period [22]. The health risk assessment of each element is based on evaluation of the risk level and is expressed in terms of a carcinogenic or non-carcinogenic health risk [23]. Slope factor (SF) for carcinogen risk characterization and the reference dose (RfD) for non-carcinogen risk characterization were also evaluated [24]. Oral ingestion pathway was considered for the study [25]. Below equation was adopted to calculate the chronic daily intake for oral and dermal adsorption pathways [26-29].

$$
C D I_{\text {oral }}=\frac{(C W \times I R \times E F \times E D)}{(B W \times A T)}
$$

Here, $\mathrm{CDI}=$ Chronic daily intake $(\mu \mathrm{g} / \mathrm{Kg} /$ day $) \mathrm{CW}=$ Concentration of trace metal in water $(\mu \mathrm{g} / \mathrm{L}), \mathrm{IR}$ $=$ Ingestion rate (L/day; 2.2 for adult 1 for Child), EF = Exposure frequency (Days/year, 365), ED = Exposure duration [Year; for oreal $=70$ for Adult, 10 for Child], BW = Body weight $(\mathrm{Kg} ; 70 \mathrm{~kg}$ for Adult, $25 \mathrm{~kg}$ for Child), AT = Average time (Days; 25,550 for Adult, 3650 for Child) [22, 28-33].

The health risk due to groundwater consumption was justified on the basis of chronic (noncarcinogenic) and carcinogenic effects. The noncarcinogenic risk was calculated as Hazard quotient (HQ) by the following equation-

$$
H Q=\frac{C D I}{R f D}
$$

Where $\mathrm{HQ}$ is hazard quotient (unitless) and $\mathrm{RfD}(\mu \mathrm{g} / \mathrm{Kg} /$ day) originates from risk-based concentration table [34]. 
For elemental risk assessment, the individual HQs are combined to form Hazard Index (HI). If the value of HQ and $\mathrm{HI}$ exceeds 1, there could be potential noncarcinogenic effects on health while $\mathrm{HI}$ less than 1 indicates the no risk of health effects [35-36].

$$
H I=H Q_{1}+H Q_{2}+\ldots . .+H Q_{n}
$$

The carcinogenic risk was measured from the calculation of CDIoral (mg/kg/day) and Slope Factor (SF) $(\mathrm{mg} / \mathrm{kg} / \mathrm{day})^{-1}$ and a range of characterization has been provided in Table $\mathbf{1}$ chronic and cancer risk assessment [37].

Table 1. Scales for chronic and carcinogenic risk assessment [31, 21]

\begin{tabular}{lllll}
\hline Risk level & HQ or HI & Chronic risk & $\begin{array}{l}\text { Calculated cases of cancer } \\
\text { occurrence }\end{array}$ & Cancer risk \\
\hline 1 & $<0.1$ & Negligible & $<1$ per 1000,000 inhabitants $\left(10^{-6}\right)$ & Very low \\
2 & $\geq 0.1<1$ & Low & $>1$ per 1000,000 inhabitants $\left(10^{-6}\right)$ & Low \\
& & & $<1$ per 100,000 inhabitants $\left(10^{-5}\right)$ & \\
3 & $\geq 1<4$ & Medium & $>1$ per 100,000 inhabitants $\left(10^{-5}\right)$ & Medium \\
& & & $<1$ per 10,000 inhabitants $\left(10^{-4}\right)$ & \\
4 & High & $>1$ per 10,000 inhabitants $\left(10^{-4}\right)$ & High \\
& & & $<1$ per 1000 inhabitants $\left(10^{-3}\right)$ & \\
5 & & & $>1$ per 1000 inhabitants $\left(10^{-3}\right)$ & Very high \\
\hline
\end{tabular}

Table 2. Descriptive Statistical Analysis ) (detailed data were provided in supplementary material 1).

\begin{tabular}{|c|c|c|c|c|c|c|c|c|}
\hline \multirow[t]{2}{*}{ Parameters } & \multirow[t]{2}{*}{ Minimum } & \multirow[t]{2}{*}{ Maximum } & \multirow[t]{2}{*}{ Mean } & \multirow{2}{*}{$\begin{array}{c}\text { Std. } \\
\text { Deviation }\end{array}$} & \multirow{2}{*}{$\begin{array}{c}\text { Bangladesh } \\
\text { Standard } \\
(1997) \\
\end{array}$} & \multicolumn{2}{|c|}{ Indian standards (2012) } & \multirow{2}{*}{$\begin{array}{l}\text { WHO } \\
(2011)\end{array}$} \\
\hline & & & & & & $\begin{array}{c}\text { Acceptable } \\
\text { Limit } \\
\end{array}$ & $\begin{array}{c}\text { Permissible } \\
\text { Limit } \\
\end{array}$ & \\
\hline Well & 10.67 & 82.3 & 24.322 & 11.82475 & & & & \\
\hline Depth (m) & & & & & & & & \\
\hline As $(\mu \mathrm{g} / \mathrm{L})$ & BDL & 113 & 19.444 & 24.75604 & 50 & 10 & 50 & 10 \\
\hline $\mathrm{Fe}(\mu \mathrm{g} / \mathrm{L})$ & BDL & 19296 & 811.353 & 2747.66231 & $300-1000$ & 300 & $\begin{array}{l}\text { No } \\
\text { relaxation }\end{array}$ & $\begin{array}{l}\text { No } \\
\text { proposed } \\
\text { value }\end{array}$ \\
\hline $\operatorname{Mn}(\mu \mathrm{g} / \mathrm{L})$ & 54 & 2716 & 455.181 & 394.11977 & 100 & 100 & 300 & 500 \\
\hline $\begin{array}{l}\mathrm{NO}_{3}^{-} \\
(\mathrm{mg} / \mathrm{L})\end{array}$ & BDL & 708.11 & 253.175 & 168.80272 & 10 & 45 & $\begin{array}{l}\text { No } \\
\text { relaxation }\end{array}$ & 50 \\
\hline
\end{tabular}



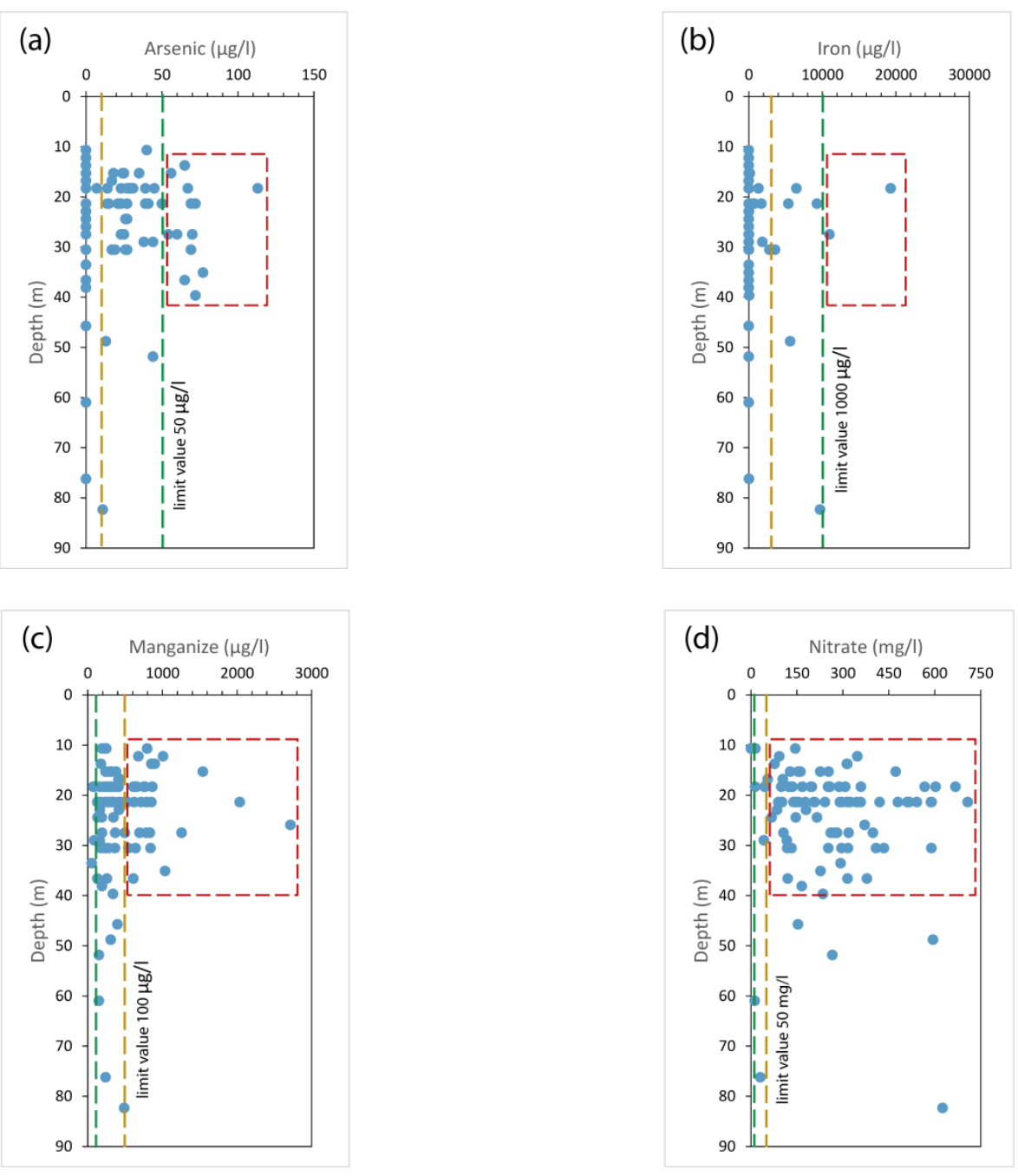

Figure 2. Depth wise water analysis. Dotted line representing recommended/limit value and the red dotted box refers the clusters of sampling points exceeding limit value for each of the parameters limited to $40 \mathrm{~m}$ depth.

\section{Results}

\subsection{Statistical Description}

The average depth wise results of 99 ground water samples for $\mathrm{As}, \mathrm{Fe}, \mathrm{Mn}$ and $\mathrm{NO}_{3}{ }^{-}$are provided in Table 1. The mean concentrations of $\mathrm{As}, \mathrm{Fe}, \mathrm{Mn}$ and $\mathrm{NO}_{3}$ - were also compared in Table 2 with the BDWS (1997), Indian Standards (2012) and WHO (2011). Statistical analysis from Table 2 represented that mean concentration of $\mathrm{NO}^{-}(253.175 \mathrm{mg} / \mathrm{L})$ exceeded the standard concentration of Bangladesh Drinking Water Standard (BDWS 1997), India (2012) and WHO (2011). Again the mean concentration of Mn (455.181 $\mu \mathrm{g} / \mathrm{L})$ was found to be greater than BDWS (1997) and Indian Standards (2012) but lesser than WHO (2011). Though the mean concentration for Fe $(811.253 \mu \mathrm{g} / \mathrm{L})$ was within the range of BDWS (1997), it crossed the parameters standardized by India (2012) and WHO (2011). The mean 
concentration of As $(19.444 \mu \mathrm{g} / \mathrm{L})$ did not exceed the limit for BDWS (1997) and permissible limit of Indian Standards (2012) but break the concentration limit given by acceptable limit of Indian Standards (2012) and WHO (2011).

Elemental depth wise distribution was also illustrated in terms of depth (m) vs. elemental concentrations $(\mu \mathrm{g} / \mathrm{L})$. [Figure 2(a-d)]. Figure 2d suggested that approximately $87.89 \%$ of groundwater samples exceeded all the standard limit values of $\mathrm{NO}_{3}{ }^{-}$in the depth range between $10 \mathrm{~m}$ $40 \mathrm{~m}$. Figure $\mathbf{2 c}, \mathbf{2 a}$ and $\mathbf{2 b}$ also showed that approximately $21.21 \%$ ground water sample for $\mathrm{Mn}$, $13.13 \%$ for As and $2.02 \%$ for Fe crossed the standard limit values in the same depth range.

Table 3. Principle component Analysis

\begin{tabular}{lll}
\hline & PC1 & PC2 \\
\hline $\mathrm{As}$ & 0.56 & -0.536 \\
$\mathrm{Fe}$ & 0.83 & -0.229 \\
$\mathrm{Mn}$ & 0.249 & 0.752 \\
$\mathrm{NO}^{-}$ & 0.691 & 0.439 \\
Eigenvalues & 1.542 & 1.099 \\
\% of Variance & 38.562 & 27.479 \\
Cumulative \% & 38.562 & 66.04 \\
\hline
\end{tabular}

\subsection{Principal Component Analysis (PCA)}

To assess inter-elemental correlation results Principal Component Analysis (PCA) of groundwater samples were analyzed and have been shown in Table 3. PCA was calculated to interpret the elemental data [38]. This powerful method helps to identify and correlate different group of elements that can be identified as possessing similar behavior and common origin [39]. The eigenvalue was considered higher than 1 on the basis of Kaiser Criterion [35]. The principal component analysis of collected ground water samples elucidated that the variables were co-related to 2 principal components in which $66.04 \%$ total variance was identified. The source components (factors) were extracted on the basis of varimax rotation [38].

Table 4. Summary of $\mathrm{HQ}$ and $\mathrm{HI}$ of As, Fe, Mn and NO3 and Carcinogenic risk of Arsenic for oral ingestion in groundwater samples (average of 99 groundwater samples) (detailed data were provided in supplementary material 1)

\begin{tabular}{|c|c|c|c|c|c|c|c|}
\hline Health Risk & $\begin{array}{l}\text { Inhabita } \\
\text { nts }\end{array}$ & $\begin{array}{l}\text { HQ for } \\
\text { As }\end{array}$ & $\begin{array}{l}\text { HQ for } \\
\mathrm{Fe}\end{array}$ & $\begin{array}{l}\text { HQ for } \\
\text { Mn }\end{array}$ & $\begin{array}{ll}\mathrm{HQ} & \text { for } \\
\mathrm{NO}_{3} & \end{array}$ & $\begin{array}{l}\text { Haza } \\
\text { rd } \\
\text { index } \\
(\mathrm{HI})\end{array}$ & $\begin{array}{l}\text { Non- } \\
\text { Carcinoge } \\
\text { nic Risk }\end{array}$ \\
\hline \multirow{3}{*}{$\begin{array}{l}\text { Non- } \\
\text { carcinogenic risk }\end{array}$} & Adult & 2.037 & 0.085 & 0.715 & 4.973 & 7.810 & High \\
\hline & Child & 2.593 & 0.108 & 0.910 & 6.329 & 9.941 & High \\
\hline & & \multicolumn{5}{|c|}{ Carcinogenic risk (CR) of As } & $\begin{array}{l}\text { Carcinoge } \\
\text { nic Risk }\end{array}$ \\
\hline
\end{tabular}




\begin{tabular}{|c|l|l|l|}
\hline \multirow{2}{*}{$\begin{array}{c}\text { Carcinogenic } \\
\text { risk }\end{array}$} & Adult & $9.2 \times 10^{-4}$ & High \\
\cline { 2 - 5 } & Child & $1.17 \times 10^{-3}$ & Very High \\
\hline
\end{tabular}

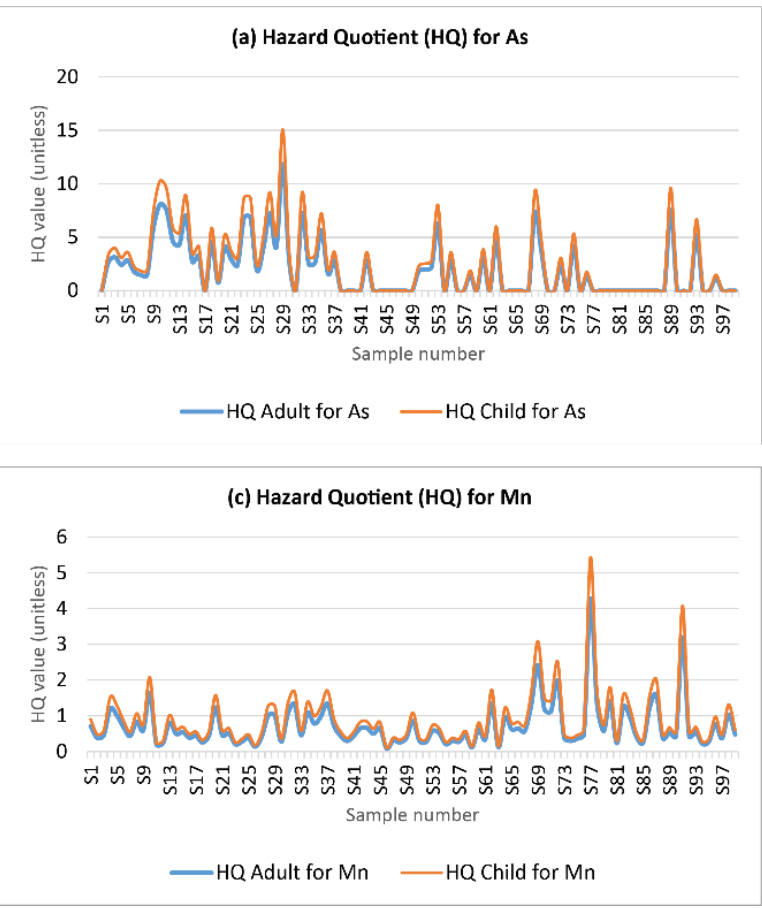

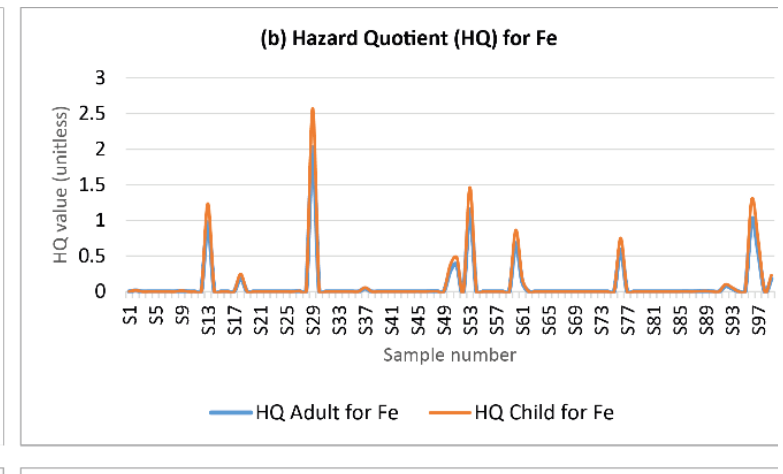

(d) Hazard Quotient (HQ) for NO3

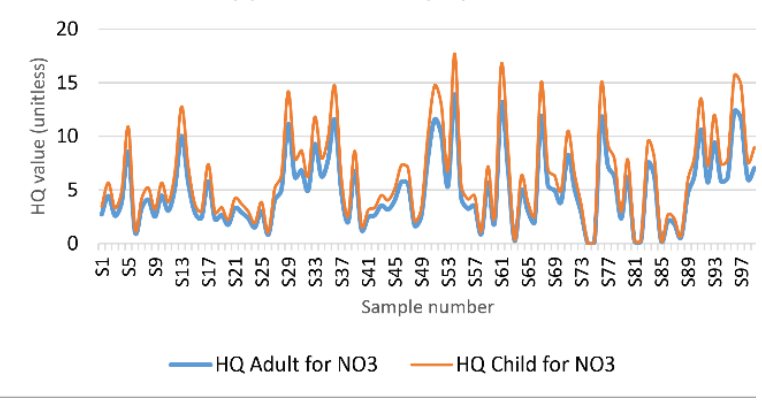

Figure 3: Hazard Quotient (HQ) oral ingestion pathway for $\mathrm{As}, \mathrm{Fe}, \mathrm{Mn}$ and $\mathrm{NO}_{3}$. Water sample identification number and HQ are plotted in X and $\mathrm{Y}$ axis respectively (Sampling points with depth provided in supplmentary material 2).

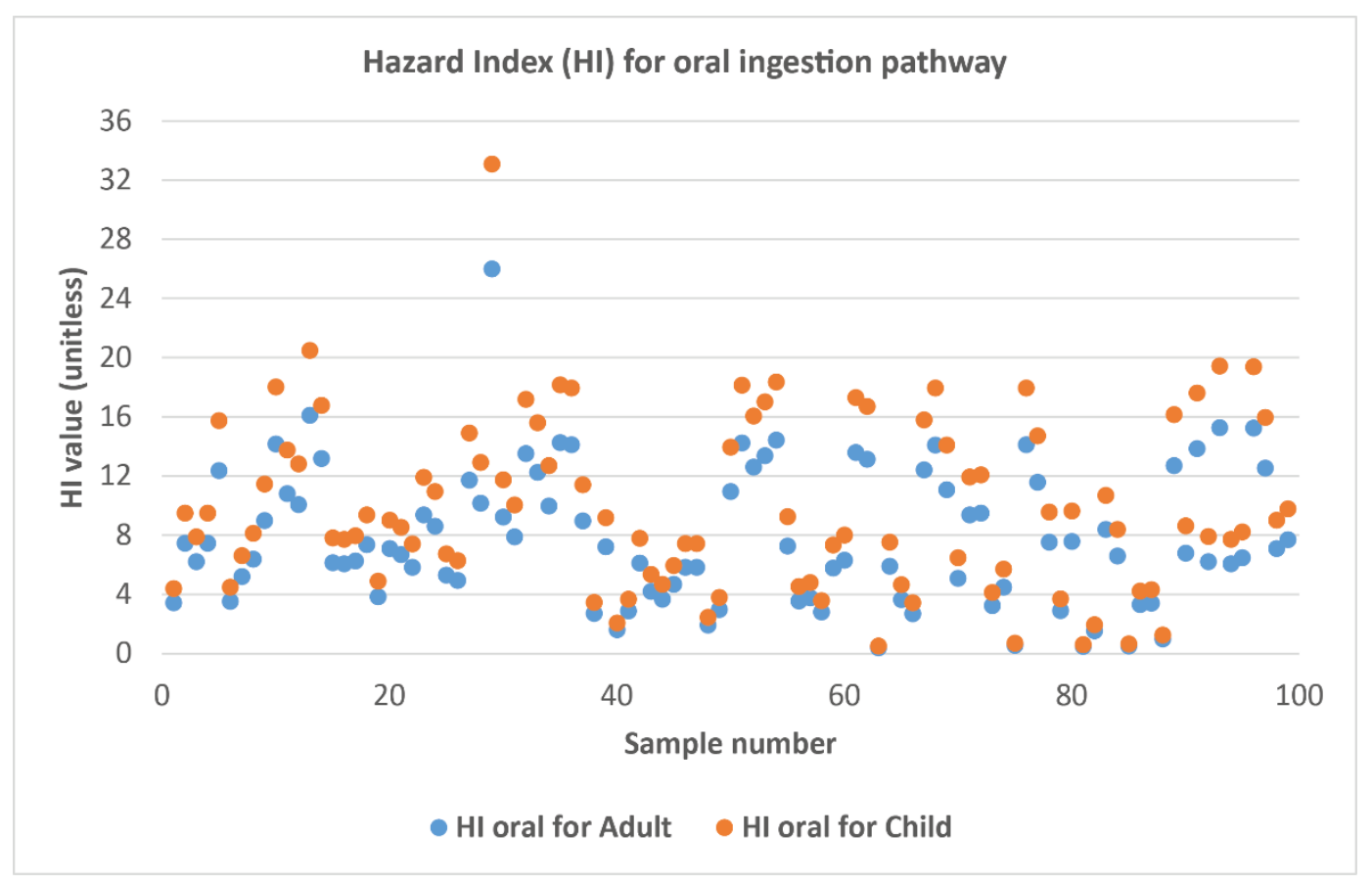


Figure 4. Hazard Index (HI) for oral ingestion pathway (Sampling points with depth provided in supplmentary material 2).

\subsection{Health Risk Assessment}

\subsubsection{Hazard Quotient (HQ) and Hazard Index (HI) measurement}

Above described table 2 and table 3 already have shown that the groundwater of this area is polluted with nitrates and trace metals. To evaluate the impact on human health related to this pollution, establishing Hazard Quotient (HQ) with related Hazard index (HI) is an important tool to calculate non-carcinogenic health risk. In this study, $\mathrm{HQ}$ and $\mathrm{HI}$ of $\mathrm{As}, \mathrm{Fe}, \mathrm{Mn}$ and $\mathrm{NO}_{3}$ for 99 ground water samples are illustrated in Figure $\mathbf{2}$ and $\mathbf{3}$. Considering average of these elements, both oral as well as dermal adsorption risks were identified in terms of non-carcinogenic risk measurement for both child and adult generation (Table 4). Oral ingestion pathway for adult and child showed high HQ level in As, $\mathrm{Fe}, \mathrm{Mn}$ and $\mathrm{NO}_{3}$. Considering oral ingestion of $\mathrm{As}, \mathrm{Fe}, \mathrm{Mn}$ and $\mathrm{NO}_{3}, \mathrm{HQ}$ values for adults were 2.037, 0.085, 0.715 and 4.973; whereas, HQ values for child were 4.321, 0.180, 1.517 and 10.549, respectively. The following order was found in respect of $\mathrm{HQ}$ for adults in oral ingestion $\mathrm{NO}_{3}>\mathrm{As}>\mathrm{Mn}>\mathrm{Fe}$. For child the order was $\mathrm{NO}_{3}>\mathrm{As}>\mathrm{Mn}>\mathrm{Fe}$ in oral ingestion. HI calculation also done for adult and child. For adult, about 75.76\% samples showed high non-carcinogenic risk while $19.19 \%$ samples showed medium non-carcinogenic risk. For child, about $83.84 \%$ samples showed high noncarcinogenic risk while $11.11 \%$ samples showed medium non-carcinogenic risk. Low noncarcinogenic health effect (5.05\% samples) was shown in both adult and child. Average hazard index result for adult and child also placed in Table 4. Results showed that both adult (HI=7.810) and child (HI=9.941) showed high non-carcinogenic risk effect.

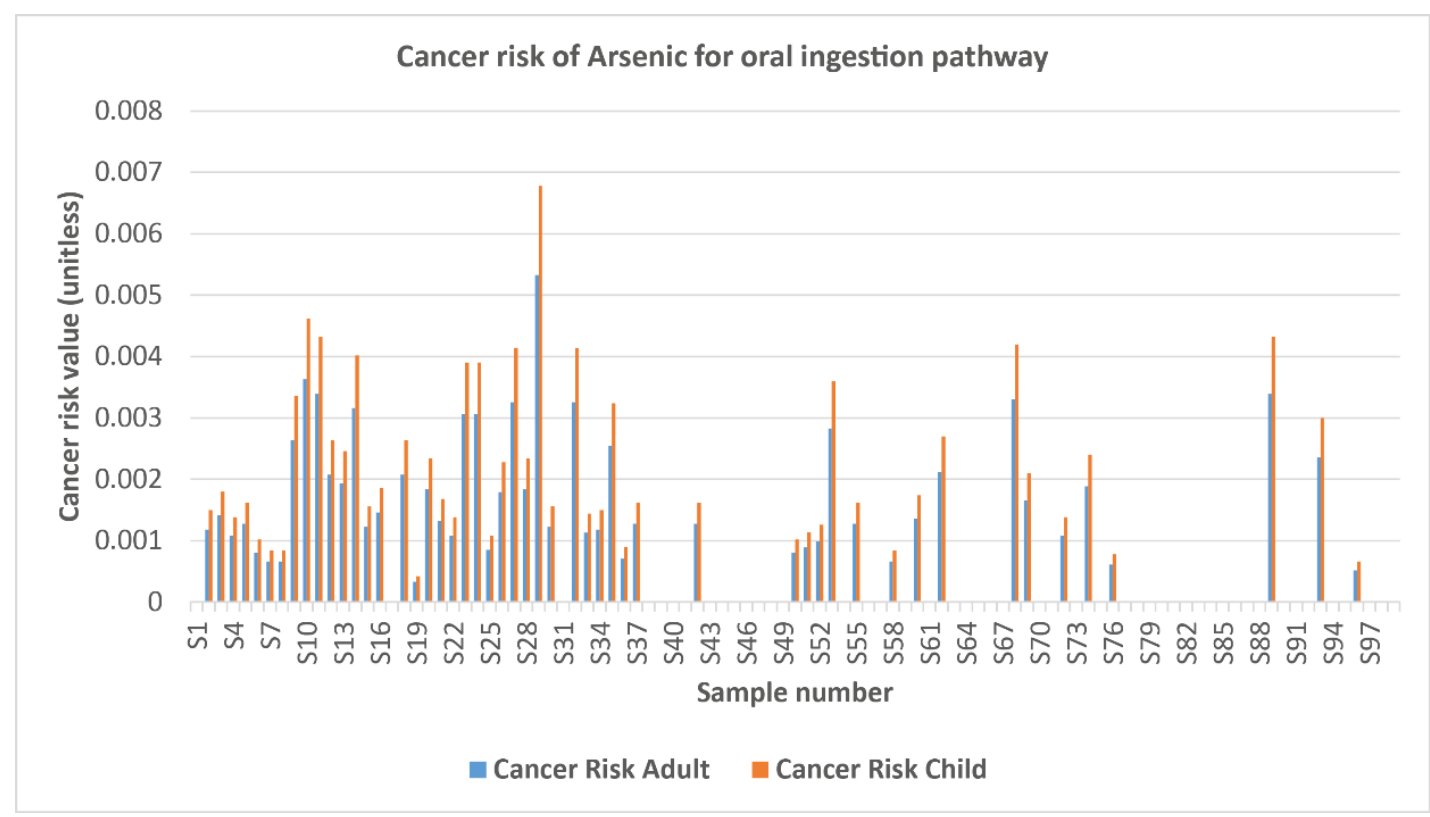

Figure 5. Cancer Risk (HI) for oral ingestion pathway (Sampling points with depth provided in supplmentary material 2). 


\subsubsection{Cancer Risk Assessment}

Cancer risk on adult and child due to As for both oral ingestion pathway was illustrated in Figure 4 and 5 and the calculated result placed in Table 4. Considering oral ingestion pathway, high $\left(9.2 \times 10^{-}\right.$ $\left.{ }^{4}\right)$ and very high $\left(1.94 \times 10^{-3}\right)$ carcinogenic risk was justified for adult and child respectively. Out of 99 samples for adult, $39.39 \%$ samples exhibited very high carcinogenic risk and $12.12 \%$ samples showed high carcinogenic risk. Moreover, for children, $42.42 \%$ samples possessed very high carcinogenic risk while $9.09 \%$ samples showed high carcinogenic risk. For both adult and children about $48.48 \%$ samples seemed to be not harmful.

\section{Discussion}

Water quality parameters reflect the level of contamination in water resources. In this study, the quality of groundwater in terms of nitrate $\left(\mathrm{NO}_{3}{ }^{-}\right)$, arsenic $(\mathrm{As})$, iron $(\mathrm{Fe})$ and manganese $(\mathrm{Mn})$ varied drastically among different sampling sites in central Bangladesh. The results has shown that the mean value of $\mathrm{NO}_{3}^{-}(253.175 \mu \mathrm{g} / \mathrm{L})$ exceeded Bangladesh standard (BDWS, 1997), Indian Standards (2012) and WHO standard (2011) (Table 2). Both the geogenic and anthropogenic sources can be the contributor of elevated level of $\mathrm{NO}_{3}$ - in groundwater of the study area e.g. application of nitrogenous fertilizer or manure slurries in agriculture and aquaculture, poor soil profile, and irrigation mechanisms. Relatively little of the $\mathrm{NO}_{3}{ }^{-}$found in natural waters is of mineral origin, most coming from organic and inorganic sources, the former including waste discharges and the latter comprising chiefly artificial fertilizers. Alongside, anthropogenic activities like sewage effluents, unsewered sanitation, and unplanned disposal of solid waste in densely populated areas may also leached $\mathrm{NO}_{3}$ into groundwater [43]. The higher occurrence of $\mathrm{NO}_{3}$ - in shallow depth groundwater was likely due to anthropogenic activities e.g. excessive use of agrochemicals and unmanaged irrigation system that could cause microbial mineralization in the ground water [1].This excess $\mathrm{NO}_{3}$ - contamination in drinking water can cause increased cancer risk [38].

Nitrogenous fertilizers rapidly convert into $\mathrm{NO}_{3}$ - in soils, are highly soluble and hence easily leachable to deep soil layers and ultimately enter into shallow aquifers [44]. For instance, sandy or sandy clay soil with high coarse texture have high water filtration rate and possibly contributing in nitrate leaching to underground waters [45]. Moreover, extensive agricultural practices in the study area may contribute in $\mathrm{NO}_{3}$ - leaching in aquifers of this area [46]. Similar $\mathrm{NO}_{3}$ - concentration increase over the acceptable limit was reported by Majumdar et al. (2008) in shallow groundwater of centralwest region of Bangladesh [44].

Interest is centered on $\mathrm{NO}_{3}{ }^{-}$concentrations in groundwater is mainly due to it's potential deleterious effects on human health. Hemoglobin carries oxygen into the blood but high level of $\mathrm{NO}_{3}$ - intake reduces the capacity of oxygen binding with hemoglobin which creates a condition referred to as methemoglobinemia or "blue baby syndrome," which may cause mortality by asphyxiation especially in newly born infants [48]. Although, $\mathrm{NO}_{3}$ - itself is not a direct toxicant but is a health hazard because of its conversion to nitrite. According to Walker (1990) when nitrate reduces to nitrite, it can undergo nitrosation reactions in the stomach with amines and amines to form a variety of $\mathrm{N}$ nitroso compounds (NOC) [49]. These $N$-nitroso compounds (NOC) are mainly carcinogens [54]. The results of this study thus indicates that groundwater from the $10 \mathrm{~m}$ to $40 \mathrm{~m}$ depth in the study area is severely polluted with $\mathrm{NO}_{3}$. Furthermore, the $\mathrm{HQ}$ and $\mathrm{HI}$ value of $\mathrm{NO}_{3}$-implicated for potential non-carcinogenic health risk in the study area both for adult and for children (table 4 and figure 3). Dellavalle et al. (2014) suggested that high dietary nitrate intake expected to have higher exposure to 
endogenously formed NOCs and increases risk of colorectal cancer [50]. Moreover, our result has been shown that children health risk due to increased $\mathrm{NO}_{3}{ }^{-}$concentration in drinking water is higher than that of adults. Similar results were reported by Zhai et al. (2017) in China [51].

The study area is also characterized with elevated levels of trace metals (As, Fe, and $\mathrm{Mn}$ ) in the groundwater. The mean concentration of all three metals is exceeds the limit of WHO standards (2011).The major potential sources of these trace metals is geogenic [2,52] and Mn might be originated from both geogenic and anthropogenic sources as depicted by the PCA analysis (Table 3). The first component (PC1) was considered to be associated with the earth's crust and the geological basin formation [31]. This component showing 38.562\% variance comprised of $\mathrm{As}, \mathrm{Fe}, \mathrm{Mn}$ and $\mathrm{NO}_{3}{ }^{-}$with high loadings. The second component (PC2) was also attributed to the geogenic source [31] and explaining $27.479 \%$ of variance (Table 3$)$. The mean value of arsenic $(19.44 \mu \mathrm{g} / \mathrm{L})$ lies within the range of BDWS (1997) standard and permissible limit of Indian Standards (2012) but exceeded the concentration limit given by acceptable limit of WHO standard (2011). This occurrence of As, Mn and Fe in the shallow depth water might be attributed to the geogenic formation of the Bengal Basin [2] as well as from anthropogenic activities [39]. Arsenic in groundwater is associated with skin damage, increased risk of cancer, and problems with circulatory system [53]. This study shows that carcinogenic risk of arsenic for oral ingestion from groundwater sample is high for child than the adults. Similar high carcinogenic risk for adult and child were also found by Rahman et al. (2017) in ground water samples of Gopalganj of Bangladesh [50], which is located southern side of our sampling area. Moreover, Chen et al. (2011) reported that exposure to arsenic in drinking water is adversely associated with mortality from heart disease [51]. Skin lesions caused by As contaminated drinking water have already been reported among adults and children in Bangladesh [52]. However, Sohel et al. (2009) stated that increased risks at low level exposure of As $(50-149 \mu \mathrm{g} / \mathrm{L})$ were observed for death due to cancers, cardiovascular disease, and infectious diseases in Bangladesh [53]. However, the HQ for Fe (children; 0.108 ) and Mn (children; 0.910 ) are relatively very lower compared to $\mathrm{NO}_{3}{ }^{-}$ and As in the study area. Though the mean concentration of Fe and Mn is quite high but the calculated HQ is within the safe limit for both adult and children in the study area. Thus the study shows that the shallow aquifer groundwater of central is polluted by $\mathrm{NO}_{3}{ }^{-}$and As with substantial human health risk.

\section{Conclusions}

The outcome of the study depicts the human health risk of $\mathrm{NO}_{3}$ and $\mathrm{As}$ by analyzing 99 ground water samples from the Central Bangladesh. The elevated occurrence of $\mathrm{NO}_{3}-$ and As is predominant within the $10 \mathrm{~m}$ to $40 \mathrm{~m}$ depth zone. Furthermore, $\mathrm{HQ}$ values of $\mathrm{NO}_{3}$ - and As are the dominant contributors in $\mathrm{HI}$ for the non-carcinogenic health risk for both adult and children. Additionally, carcinogenic risk due to As is also high in the study area. Finally, the shallow tube-well is not safe for drinking water collection in the study area. However, further study warrants considering wider area with spatial and temporal variability to predict health risk more precisely including the human level direct detection of the $\mathrm{NO}_{3}{ }^{-}$and $\mathrm{As}$.

Author Contributions: “Conceptualization, M.M.R. and M.B.D.; Methodology M.M.R. M.B.D. and M.I.M.; Software, M.M.R. M.B.D. and M.I.M; Validation, M.M.R. M.B.D. and M.K.U.; Formal Analysis, M.M.R. M.B.D. and M.I.M; Investigation, M.M.R. K.F.B.H. M.K.U. and M.I.M; Data Curation, M.M.R. M.S. and M.B.D.; Writing- 
Original Draft Preparation, M.M.R. M.S.H. and K.F.B.H; Writing-Review \& Editing, M.M.R. M.T.S. M.S.H. and S.A.; Visualization, M.M.R. S.A. and M.S.; Supervision, M.M.R. M.T.S. and M.K.U.

Conflicts of Interest: The authors declare no conflict of interest.

\section{References}

[1]. Sharma, C.; Mahajan, A.; Garg, U.K. Fluoride and nitrated in ground water of south-western Punjab, India- occurance, distribution and statistical analysis. Desalination Water Treat. 2014, 57, 1-12.

[2]. Rahman, M.M.; Sultana, R.; Shammi, M.; Bikash, J.; Ahmed, T.; Maruo, M.; Kurasaki, M.; Uddin, M.K. Assessment of the status of groundwater arsenic at SingairUpazila, Manikganj, Bangladesh; Exploring the correlation with the other metals and ions. Expo. Health 2016, 8, 217-225.

[3]. Anawar, H.M.; Akai, J.; Mostofa, K.M.G.; Safiullah, S., Tareq, S.M. Arsenic poisoning in groundwater Health risk and geochemical sources in Bangladesh. Environ. Int.2002, 27, 597- 604.

[4]. Ritter, L.; Solomon, K.; Sibley, P.; Hall, K.; Keen, P.; Mattu, G.; Linton, B. Sources, pathways and relative risks of contaminants in surface water and ground water: a perspective prepared for the Walkerton Inquiry. J. Toxicol. Environ. Health 2002, 65, 1-142.

[5]. Buchet, J.P.; Lison, D. Clues and Uncertainities in the risk assessment of arsenic in drinking water. Food Chem. Toxicol.2000, 38, S81-S85.

[6]. Kavcar, P.; Sofuoglu, A.; Sofuohlu, S.C. A health risk assessment for exposure to trace metals via drinking water ingestion pathway. Int. J. Hyg. Environ. Health 2009, 212, 216-227.

[7]. Muhib, M.I.; Chowdhury, M.A.J.; Easha, N.J., Rahman, M.M, Shammi, M.; Fardous, Z.; Bari, M.L.; Uddin, M.K.; Kurasaki, M.; Alam, M.K. Investigation of heavy metal contents in Cow milk samples from area of Dhaka, Bangladesh. Int. J. Food Contam.2016, 3, 16.

[8]. Wasserman A.G.;Liu, X.; Parvez, F.; Ahsan, H.; Levy, D.; Factor-Lltvak, P.; Kline, J.; Geen, A.V.; Slavkovich, V.;Lolacono, N.G.; Cheng, Z.; Zheng, Y.; Graziano, J.H. Water Manganese Exposure and Children's Intellectual Function In Araihazar, Bangladesh. Environ. Earth Perspec.2006, 114, 124-129.

[9]. Merrill, R.D.; Shamim, A.A.; Ali, H.; Jahan, N.; Labrique, A.B.; Schulze, K.; Christian, P.; West Jr, K.P. Iron status of women is associated with the iron concentration of potable groundwater in rural Bangladesh. J. Nutr.2011, 141, 944-9.

[10]. Heming, N.; Montravers, P.; Lasocki, S. Iron deficiency in critically ill patients:highlighting the role of hepcidin. Crit. Care.2011, 15, 210.

[11]. El-Midaoui, A.; Elhannouni, F.; Taky, M.; Chay, L.; Sahli, M.A.M.; Echihabi, L.; Hafsi, M. Optimization of nitrate removal operation from ground water by electrodialysis. Sep. Purif. Technol. 2002, 29, 235244.

[12]. Pannala, A.S.; Mani, A.R.; Spencer, J.P.E.; Skinner, V.; Bruckdorfer, K.R.; Moore, K.P.; Rice-Evans, C.A. The effect of dietary nitrate on salivary, plasma, and urinary nitrate metabolism in humans. Free Radic. Biol. Med.2003, 34, 576-584.

[13]. Lohumi, N.; Gosain, S.; Jain, A.; Gupta, V.K.; Verma, K.K. Determination of nitrate in environmental water samples by conversion into nitrophenols and solid phase extraction-spectrophotometry, liquid chromatography or gas chromatography-mass spectrometry, Anal. Chim. Acta 2004, 505, 231-237.

[14]. Fewtrell, L. Drinking-water nitrate, methemoglobinemia, and global burden of disease: A discussion. Environ. Health Perspect.2004, 112, 1371-1374.

[15]. Greer, F.R.; Shannon, M. Infant methemoglobinemia: The role of dietary nitrate in food and water. Paediatrics2005, 116, 784-786.

[16]. Ward, M.H.; DeKok, T.M.; Levallois, P.; Brender, J.; Gulis, G.; Nolan, B.T.; Derslice, J.V. Workgroup report: Drinking-water nitrate and health-Recent findings and research needs, Environ.Health Perspect.2005, 113, 1607-1614.

[17]. Rachid, A.; Christophe, M.; Marc, B.; Laure, O.; Sylvie, T.; Paul, P. Methemoglobinemia by cerium nitrate poisoning, Burns2006, 32, 1060-1061.

[18]. Ma, H.W.; Hung, M.L.; Chen, P.C. A systemic health risk assessment for chromium cycle in Taiwan. Environ. Int.2007, 33, 206-218.

[19]. Momot, O.; Synzynys, B. Toxic aluminium and heavy metals in ground wate of middle Russis: health risk assessment. Int. J. Environ. Res. Pub. Health 2005, 2, 214-218.

[20]. Wu, B.; Zhang, Y.; Zhang, X.; Cheng, S. Health risk from exposure of organic pollutants through drinking water consumption in Nanjing, China. Bull.Environ.Contam. Toxicol. 2010, 84, 46-50. 
[21]. Bortey-Sam, N.; Nakayama, S.M.; Ikenaka, Y.; Akoto, O.; Baidoo, E.; Mizukawa, H.; Ishizuka, M. Health risk assessment of heavy metals and metalloid in drinking water from communities near gold mines in Tarkwa, Ghana. Environ. Monit. Assess. 2015, 187, 397. DOI 10.1007/s10661-015-4630-3

[22]. USEPA (US Environmental Protection Agency). National primary/secondary and drinking water regulations 2009. Washington, D.C.

[23]. Lim, H.S.; Lee, J.S.; Chon, H.T.; Sager, M. Heavy metal contamination and health risk assessment in the vicinity of the abandoned SongcheonAu-Ag mine in Korea. J. Geochem. Explor. 2008, 96, 223-230.

[24]. Ning, L.; Ni, T.; Xia, J.; Dai, M.; He, C.; Lu, G. Non-carcinogenic risks induced by metals in drinking source water of Jiangsu Province, China. Environ. Monit. Assess.2011, 177, 449-456. DOI 10.1007/s10661010-1646-6.

[25]. USEPA (US Environmental Protection Agency).Risk Assessment Guidance for Superfund Volume I Human Health Evaluation Manual (Part A). United States Environmental Protection Agency 1989, Washington, D.C.

[26]. Giri, S.; Singh, A.K. Human health risk assessment via drinking water pathway due to metal contamination in the ground water of Subarnarekha river basin, India. Environ. Monit. Assess. 2015, $187,63$.

[27]. Wongsasuluk, P.; Chotpantarat, S.; Siriwong, W.; Robson, M. Heavy metal contamination and human health risk assessment indrinking water from shallow groundwater wells in an agricultural area in UbonRatchathani province, Thailand. Environ. Geochem. Health 2013. 36, 169-182. DOI.10.1007/s10653013-9537-8

[28]. USEPA (US Environmental Protection Agency). Risk assessment guidance for superfund (RAGS), volume I: human health evaluation manual (part E) interim. United States Environmental Protection Agency 1993, Washington, D.C.

[29]. ECETOC (European Center for Ecotoxicology of Chemical). Aquatic Toxicity of Mixtures. Technical Report. 2001, 80, Brussels.

[30]. USEPA (US Environmental Protection Agency). Baseline human health risk assessment, 2001. Vasquez Boulevard and 1-70 superfund site, Denver CO.

[31]. USEPA (US Environmental Protection Agency). A risk assessment-multiway exposure spreadsheet calculation tool. United States Environmental Protection Agency, 1999. Washington, D.C.

[32]. Weyer, P.J.; Cerhan, J.R.; Kross, B.C.; Hallberg, G.R.; Kantamneni, J.; Breuer, G.; Jones, M.P.; Zheng, W.; Lynch, C.F. Municipal drinking water nitrate level and cancer risk in older women: the Iowa women's health study. Epidemiology 2001, 11, 3.

[33]. Kavcara, P.; Sofuoglu, A.; Sofuoglu, S.C. A health risk assessment for exposure to trace metals via drinking water ingestion pathway. Int. J. Hyg. Environ. Health 2009, 212, $216-227$.

[34]. Tahri, M.; Beny"Ich, F.; Bounakhla, M.; Bilal, E.; Gruffat, J.J.; Moutte, J. Multivariate analysis of heavy metal contents in soil, sediment and water in the region of Meknes (Central Morocco). Environ.Monit. Assess. 2005, 102, 405-417.

[35]. Kaiser, H.F. The application of electronic computers to factor analysis. Educ. Physiol. Meas. 1960, 20, 141-151.

[36]. Sikder, M.T.; Kihara, Y.; Yasuda, M.; Yustiawati,; Mihara, Y.; Tanaka, S.; Odgerel, D.; Mijiddorj, B.; Syawal, S.M.; Hosokawa, T.; Saito, T.; Kurasaki, M. River Water Pollution in Developed and Developing Countries: Judge and Assessment of Physicochemical Characteristics and Selected Dissolved Metal Concentration, Clean- soil air and water 2013, 41, 60-68.

[37]. Kundu, M.C.; Mandal, B.; Sarkar, D. Assessment of the potential hazardous of nitrate contamination in surface and groundwater in a heavily fertilized and intensively cultivated district of India. Environ. Monit. Assess. 2008, 146, 183-189

[38]. Suthara, S.; Bishnoib, P.; Singh, S.; Mutiyara, P.K.; Nemaa, A.K.; Patil. N.S. Nitrate contamination in groundwater of some rural areas of Rajasthan, India. J. Hazard. Mater. 2009, 171, 189-199

[39]. Kundu, M.C.; Mandal, B. Agriculture activities influence nitrate and fluoride contamination in drinking groundwater of an intensively cultivated district in India, Water air Soil Pollut. 2008. doi:10.1007/s1270-008-9842-5

[40]. Wakida, F.D.; Lerner, D.N. Non-agriculture sources of groundwater nitrogen: a review and case study. Water Res. 2005, 39, 3-16.

[41]. Reddy, A.G.S.; Kumar, K.N.; Rao, D.S.; Rao, S.S. Assessment of nitrate contamination due to groundwater pollution in north eastern part of Anantapur District, A.P., India, Environ. Monit. Assess. 2009, 148, 463-476. 
[42]. Walker, R. Nitrates nitrites and N-nitroso compounds: a review of the occurrence in food and diet and the toxicological implications. Food Addit. Contam. 1990, 7, 717-768.).

[43]. Tricker, A.R.; Preussmann, R. Carcinogenic N-nitrosamines in the diet: occurrence, formation, mechanisms and carcinogenic potential. Mutat. Res. 1991, 259, 277-289.

[44]. Majumder, R.K.; Hasnat, M.A.; Hossain, S.; Ikeue, K.; Machida, M. An exploration of nitrate concentrations in groundwater aquifers of central-west region of Bangladesh. J. Hazard. Mater. 2008, $159,536-543$

[45]. Dellavalle, C.T.; Xiao, Q.; Yang, G.; Shu, X.O.; Aschebrook-Kilfoy, B.; Zheng, W.; Lan, L.H.; Ji, B.T.; Rothman, N.; Chow, W.H.; Gao, Y.T.; Ward, M.H. Dietary nitrate and nitrite intake and risk of colorectal cancer in the Shanghai Women's Health Study. Int J Cancer. 2014, 134(12), 2917-2926. Doi: 10.1002/ijc.28612.

[46]. Zhai, Y.; Zhao, X.; Teng, Y.; Li, X.; Zhang, J.; Wu, J.; Zuo, R. Groundwater nitrate pollution and human health risk assessment by using HHRA model in an agricultural area, NE China. Ecotoxicol. Environ. Saf. 2017, 137, 130-142

[47]. Li, P.; Wu, J.; Qian, H.; Lyu, X.; Liu. H. Origin and assessment of groundwater pollution and associated health risk: a case study in an industrial park, northwest China. Environ. Geochem. Health, 2013.

[48]. Smith, L. A.; Means, J. L.; Chen A.; et al., Remedial Options for Metals-Contaminated Sites, Lewis Publishers, Boca Raton, Fla, USA,, 1995.

[49]. Bodek, I.; Lyman, W. J.; Reehl, W. F.; Rosenblatt, D. H. Environmental Inorganic Chemistry: Properties, Processes and Estimation Methods, Pergamon Press, Elmsford, NY, USA, 1988

[50]. Rahman, M.M.; Islam, M.A.; Bodrud-Doza, M.; Muhib, M.I.; Zahid, A.; Shammi, M.; Tareq, S.M.; Kurasaki, M. Spatio-temporal assessment of groundwater quality and human health risk: a case study in Gopalganj, Bangladesh.Expo. Health 2017, DOI.10.1007/s12403-017-0253-y

[51]. Chen, Y.; Graziano, J.H.; Parvez, F.; Liu, M.; Slavkovich, V.; Kalra, T.;Argos, M.; Islam, T.; Ahmed, A.; Rakibuz-Zaman, M.; Hasan, R.; Sarwar, G.; Levy, D.; Geen, A.V.; Ahsan, H. Arsenic exposure from drinking water and mortality from cardiovascular disease in Bangladesh: prospective cohort study. BMJ 2011, 342, d2431

[52]. Das, B.; Rahman, M.M.;Nayak, B.; Pal, A.; Chowdhury, U.K.; Mukherjee, S.C.;Saha, K.C.;Pati, S.;Quamruzzaman, Q.;Chakraborti, D. Groundwater arsenic contamination, its health effects and approach for mitigation in West Bengal, India and Bangladesh. Water Qual. Expo. Health 2009, 1, 5-21. DOI.10.1007/s12403-008-0002-3

[53]. Sohel, N.; Persson, L.A.; Rahman, M.; Streatfield, P.K.; Yunus, M.; Ekström, E.C.; Vahter, M. Arsenic in Drinking Water and Adult Mortality A Population-based Cohort Study in Rural Bangladesh. Epidemiology 2009, 20, 824-830 